\author{
Lubov Semiv \\ University of Banking of the National Bank of Ukraine \\ Lviv Institute of Banking Business \\ nроспект Т. Шевченка, 9 \\ semivlk@rambler.ru \\ Yulia Hvozdovych \\ NAS Ukraine \\ Institute for the Regional Research \\ Kozelnytska st. 4 \\ Lviv, 79026, Ukraine \\ cheska4x@gmail.com
}

\begin{abstract}
The migration of high-skilled youth is a natural phenomenon in terms of globalization and brings considerable benefits to countries that own the intellectual capital of these workers. The main trends related to the international youth migration that can cause the further threat of the "brain drain" in Ukraine are explored, namely: labour migration and "brain waste", educational migration, migration for international scientific cooperation and professional training and "idea migration". Some policy measures that can encourage an effective process of "brain circulation" in Ukraine are proposed.
\end{abstract}

Keywords: youth, intellectual migration, labour migration, academic mobility, outsourcing.

JEL Classification: F22, J24, J61, O15.

\title{
INTRODUCTION
}

Ukraine's admission to the Bologna process in 2005 has created favourable conditions for students, teachers and scientists for a gradual entry into the civilized mainstream of educational and scientific mobility (academic mobility). This caused an opportunity for their personal development, strengthening cooperation between researchers and research institutions at international level and within Ukraine, improving the quality of higher education and research activity.

But fortunately for many young people especially from developing countries, such as Ukraine, the process of studying abroad is the first step in establishing permanent residence in the host country and can cause the phenomenon of "brain drain" or intellectual emigration. The waste of skills or "brain waste" that occurs 
when highly skilled workers migrate into forms of employment not requiring the application of the skills and experience applied in the former job, is the another chronic form and outcome of Ukrainian labour emigration. The new trend of "idea migration" appeared recently with the improvement of communicational technologies and new forms of work organization and training (as outsourcing, crowd-sourcing, e-learning) and does not involve physical movement of the creator, but leads to the outflow of progressive ideas abroad. In such context the problem of potential intellectual migration in Ukraine acquires a special significance of correct migration policy aimed to turn a negative phenomenon of "brain drain" (or even worse - 'brain waste") into the "brain gain" and "brain circulation".

The problem of migration from Ukraine and factors affecting emigration mood has been challenging a great interest of Ukrainian researchers (Pirozhkov S., Malinovska O., Khomra O., 2003; Libanova E., Poznyak O., 2002; Balakireva, Valkovana, 2006). Thus, Nikolayevskyy (2010) studies recent trends in intellectual migration and consider it to be one of the main problem of modern Ukrainian society. O. P'yatkovska (2012) stresses that the fifth wave of immigration that has appeared today, refers to highlyskilled youth. V. Kipen (2011) asserts that the "pushing" factors (the counteraction between the individual development of needs, capabilities and the conditions to satisfy them), not "pulling", are dominant in emigration mood of young Ukrainians.

At the same time foreign experts (L. Lowell, A. Findlay and E. Stewart, 2004) emphasize that return migration is thought to generate significant benefits for the migrant-sending country. Especially in the case of skilled returnees, their newly accrued skills, taste for innovation, and networks can be advantageous.

Thus, the main aims of the article are: to highlight new tendencies in intellectual mobility of Ukrainian youth; to define if there is a potential danger of "brain drain"; and to find/suggest possible actions for its' solution via "brain gain" to "brain circulation".

\section{MIGRATION MOOD}

There is no exact data on the number of citizens who have recently emigrated abroad, as well as no information about what part of all emigrants makes youth. But the fact that emigration from Ukraine is becoming more widespread can be proved by empirical evidence and social research.

According to the survey that was held by the Fund "Democratic Initiatives" jointly with the "Ukrainian Sociology Service" ( "Europe without barriers", 2010) only 13.8\% of youth aged 18-34 years had the intention to leave their own country for permanent residence. More often young Ukrainians were willing to stay abroad for some time (29.9\%). The labour migration was the main purpose for visiting other countries (65.1\%), 30.1\% of youth realized their tourist interest. Compared with 2003 the desire of young Ukrainians to work abroad has increased 2.9 times (from $22.4 \%$ to $65.1 \%$ ).

DEC Education Agency (N. Tarchenko, 2011) found that the number of Ukrainian students willing to study outside Ukraine for the past 5 years has increased ten times The majority of Ukrainian students prefer to study for a master's degree abroad and $30 \%$ of students prefer going abroad to obtain a complete higher education.

Another survey (Ukrainian centre for social reform, 2009) figured out that $17 \%$ of Ukrainians working abroad had no desire or ability to return back Ukraine and more than half of them $(55,9 \%)$ were young persons aged 15 to 34 years.

The main "pushing" factors, why young people from Ukraine with tertiary education and perspectives in scientific or innovation career are leaving the country today are (Pirozhkov S., Malinovska O., Khomra O., 2003; Balakireva, Valkovana, 2006): 1) the high unemployment rate in Ukraine; 2) the low level of 
employment according to the specialty; 3) the low level of material and technical basis for scientific research; 4) the salary divergence in Ukraine and abroad; 5) institutional barriers to perform international cooperation; 6) the poor innovation infrastructure, complicated mechanism of knowledge transfer and imperfect venture capital market; 7) housing problems and others.

\section{LABOUR MIGRATION AND "BRAIN WASTE”}

According to the statistic data (2010) the number of Ukrainian youth working abroad has increased in the last ten years. In 2006 there was $25 \%$ share of Ukrainian youth working abroad that left Ukraine during the latest 2-3 years, in 2009 this share raised and now it counts $29 \%$. The half part of these emigrants has gained higher education in Ukraine.

Thus, $47 \%$ of young people that have been working abroad for last years were engaged in construction, $19 \%$ fulfilled agricultural works, $12 \%$ were employed in trading. Housekeeping was the main job for the $10 \%$ of the youth, $8 \%$ took care after the retirees and children. The workplace of professionals, experts and technical staff occupied only 6.0\% of migrant workers (Boyko Z. 2010). This evidence shows that a significant proportion of migrants had an unqualified job that didn't correspond to their educational level. It is worth to notice that in the presence of relevant vacant places in the national labour market, the main reason of labour migration is not a high unemployment rate in Ukraine but the low salary for the relevant work.

Migration processes between Ukraine and other countries have mainly "emigrational" nature, because the number of "gone" youth exceeds 2-20 times (it depends on the country) the number of "arrived" youth. In 2009 from Ukraine to Russia went 37801 person and came back 19427; to Germany went 9027 and came back 269; to USA went 4150 and came back only 319. Despite the illegal status, not prestigious job and adaptation difficulties there are still $15 \%$ of youth that decide not to return from different summer programs like Work\&Travel (StarTravel agency, 2010).

\section{EDUCATIONAL MIGRATION}

The increasing number of foreign students in the world is driven by several factors. The first is the rising numbers of young people completing secondary education and continuing on to tertiary education. The second factor causing the rising number of foreign students is the increasing affluence in many developing countries, which has made it possible for more parents to afford the cost of educating their children abroad. The third factor behind growing student mobility is the globalization of education, be it through the establishment of foreign branches of prestigious Western universities in developing countries or via the promotion of student mobility within integrated markets, such as within the European Union or between the countries of the Pacific and Australia (United Nations, 2011).

The main forms of obtaining foreign education for Ukrainians are:

- Obtaining complete higher education in foreign country;

- Receiving a diploma simultaneously from Ukrainian and foreign university within the bilateral agreements between universities (several universities offer their students to gain basic Ukrainian higher education and get a foreign degree, but the quality of such education is often questionable);

- Student internships and exchange programs;

- Postgraduate 1-2 year educational programs based on students grants or at their own expense. Ukrainian students get such grants mostly from: Poland, Slovakia, USA and Germany;

- Short-term internship or targeted training for specific specialists (seminars, conferences etc.). 
The greatest share of European Higher Education Area (EHEA) students enrolled for a degree study in another EHEA country come from Germany, and this is followed by France, Russia, Ukraine, Italy, Poland, Slovakia and Greece and their quantity tends to increase from year to year. Thus, if in 200720.336 Ukrainians have been gaining higher education in EHEA, then in 2009 their number has risen to 30459. [22] Most Ukrainian students have been studying in Germany (9222), Russia (6922), Poland (2672), USA (1912), Hungary (1475) and France (1099). The increasing tendency of the number of Ukrainian students studying abroad is shown (Table 1$)$.

Table 1

The number of Ukrainian student studying abroad according to the host country

\begin{tabular}{|c|c|c|c|c|c|}
\hline \multirow[b]{2}{*}{ The host country } & \multicolumn{2}{|r|}{2004} & \multicolumn{2}{|r|}{2006} & \multirow{2}{*}{$\begin{array}{c}\% \text { of all foreign } \\
\text { students from } \\
\text { Ukraine (2006) }\end{array}$} \\
\hline & $\begin{array}{l}\text { Ukrainian } \\
\text { students, } \\
\text { number }\end{array}$ & $\begin{array}{c}\% \text { among } \\
\text { all foreign students } \\
\text { in host country }\end{array}$ & $\begin{array}{l}\text { Ukrainian stu- } \\
\text { dents, number }\end{array}$ & $\begin{array}{l}\% \text { among } \\
\text { all foreign students in } \\
\text { host country }\end{array}$ & \\
\hline Germany & 4959 & $2,6 \%$ & 9222 & $3.6 \%$ & $35.3 \%$ \\
\hline Russia & - & - & 6922 & $14,6 \%$ & $26.5 \%$ \\
\hline Poland & 1800 & $23,9 \%$ & 2672 & $20.5 \%$ & $10.2 \%$ \\
\hline USA & - & - & 1912 & $7.1 \%$ & $7,3 \%$ \\
\hline Hungary & 1005 & $8,2 \%$ & 1475 & $9.8 \%$ & $5,6 \%$ \\
\hline France & - & - & 1066 & $4 \%$ & $4,0 \%$ \\
\hline Czech Republic & 302 & $2,9 \%$ & 774 & $3.2 \%$ & $2,9 \%$ \\
\hline UK & - & - & 524 & $1.9 \%$ & $2,0 \%$ \\
\hline $\begin{array}{l}\text { The Republic of } \\
\text { Moldova }\end{array}$ & - & - & 512 & $26,6 \%$ & $1,9 \%$ \\
\hline Romania & 782 & $8 \%$ & 382 & $3.1 \%$ & $1,4 \%$ \\
\hline Bulgaria & 435 & $5,4 \%$ & 319 & $3.4 \%$ & $1,2 \%$ \\
\hline Greece & 61 & $0,5 \%$ & 202 & $1 \%$ & $0,7 \%$ \\
\hline Estonia & 21 & $1,9 \%$ & 95 & $4.3 \%$ & $0,3 \%$ \\
\hline Slovakia & 135 & $8,2 \%$ & 75 & $3.7 \%$ & $0,2 \%$ \\
\hline
\end{tabular}

Source: Kelo M, Teichler U., Wächter B. (eds.) EURODATA - Student mobility in European higher education -

Bonn: Lemmens Verlags- \& Mediengesellschaft, 2006; Mobility Barometer by Conor Cradden on behalf of Education International \& the European Students Union Education International \& European Students Union, Printed in Belgium, 2008; Teichler U, Ferencz I., Wächter B. (eds.) Mapping mobility in European higher education, Vol. I: Overview and trends, Brussels. June 2011.

The data's shown in Table 1 demonstrate: 1) that the number of Ukrainian students studying abroad had an increasing tendency during 2004-2006 (fortunately, there is no more recent information) and 2) that increased student mobility has been happening and could continue happening without the Bologna Process.

With the ratification of Bologna agreements in Ukraine in 2005, several European students' mobility programs have started proceeding in the country, as DAAD (Germany), OAD (Austria), and TEMPUS $(\mathrm{EU})$ and others. EU Socrates-Erasmus and Leonardo large-scale programs are of much importance for Ukraine. But, the scope of these entire programs share in Ukraine is extremely limited mainly because of the delay in reforming the higher education system in the country especially in the autonomy of universities. 
Within the framework of the Tempus program since 1993 only 214 grants for individual mobility were given to Ukrainian students. Since 2004, just 158 Ukrainian students and 35 scientists received scholarships for study by Erasmus Mundus program (National Tempus office in Ukraine, 2010).

The more popular and available for Ukrainian youth are the Grande programs provided by the certain country, as DAAD (Germany) or Fulbright (USA). The number of grants intended for Eastern and Central Europe by DAAD has been increasing annually by $10 \%$, in particular this includes Ukraine, where in 2010 about 1,100 students and 220 teachers received the scholarship (DAAD office, 2010). Another program held by Fulbright Foundation and American Councils enables near 120 students from Ukraine annually to establish their scientific practice in USA (Fulbright Ukraine, 2010).

This evidence shows that mobility is not likely being fully realized by the Bologna Process in Ukraine, but there is a constant tendency of increasing number of Ukrainian students studying abroad.

\section{INTERNATIONAL SCIENTIFIC COOPERATION AND PROFESSIONAL TRAINING}

The value of academic mobility must not be diminishing today, especially for doctoral students and young scientists, for whom mobility is an important tool for the immersion into the research process and the diversification of their research or teaching activities. There are different opportunities for youth to be involved into the interuniversity or international scientific cooperation within the European or other programs (TEMPUS-TACIS, TACIS-Delfa, EURECA, TIME, Marie Curie and others).

In 2007-2010, 601 Ukrainian teams took part in the 430 proposals submitted under 83 competitions according to the $7^{\text {th }}$ framework program of EU. Only 112 of them won the tender offer and have been selected for funding in the amount of 7.96 million euro's. The success rate of Ukraine, defined as the ratio of the expected financing to the proposed financing $(13,2 \%)$, is considerably less than the average for all countries FP7 participants (20.31\%), but corresponds to the new EU countries (13.01\%) (Y. Supel. 2010).

In the previous 6th Framework Programme for Research (FP6) Doctoral candidates from Ukraine were among the most active participants in Marie Curie Actions within EU neighbouring countries and provided $13 \%$ of the total number of participants and yielded only to Russia (Technopolis Group, 2010).

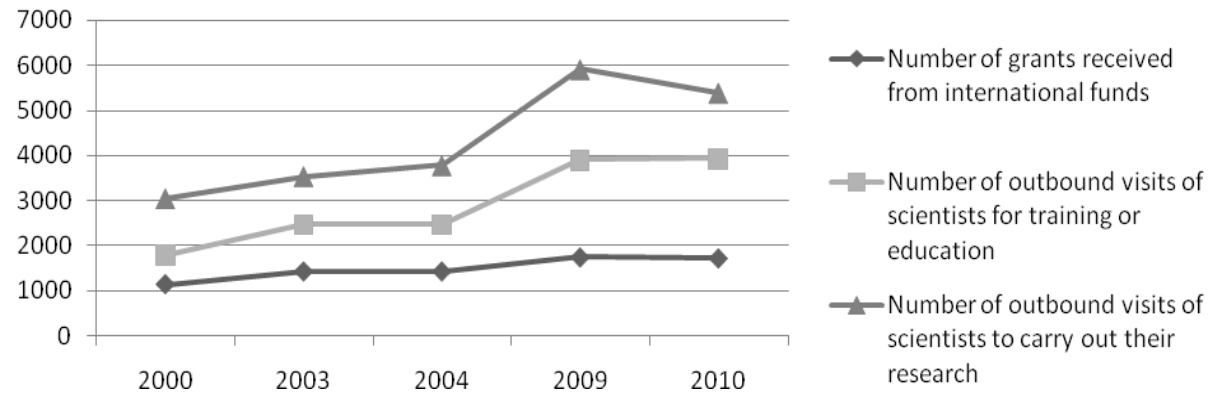

Fig.1 International cooperation of Ukrainian scientists (2000-2010)

Source: State Statistics Service of Ukraine 
We can also observe an upward trend in the level of international cooperation of Ukrainian scientists in the last 10 years. In particular, there was an increase in the number of grants received from international funds (from 1,138 in 2000 to 1,723 in 2010), a growing number of outbound visits for training or education (1780 in 2000 to 3,933 in 2010), and the substantive growth of outbound visits for the purpose to carry out a scientific research (from 3052 in 2000 to 5,291 in 2010) (Figure 1).

Figure 1 shows that the level of scientific cooperation between Ukrainian scientists and international community has grown almost two times from 2000 till 2010. On the one hand this tendency is a good evidence of Ukrainian entry into the international scientific arena. On the other hand it must be realized that such temporary movements increases the likelihood for following emigration: after the return a specialist can realize his dissatisfaction with the quality of life in Ukraine, low technical base for scientific work, inability to use the research results, an occupied workplace, and therefore be willing to look for new trips abroad.

\section{IDEA MIGRATION}

A form of brain circulation unimpeded by physical borders and unconstrained by national boundaries or even better a new form of brain drain that does not directly involve mobility has emerged recently and grown in importance as outsourcing, overseas consultancy, scientific programs for foreign clients on grant basis have emerged as current day avenues of knowledge migration.

Today Ukraine shows the high rates of market growth and leaves other countries far behind in terms of the volume of IT outsourcing services exported and appears to be one of the biggest nearshore outsourcing country for Europe (especially for Central and Scandinavian countries) and offshore for USA, Canada and Asia countries. In 2010 Ukraine was at the 11 th place in the top-20 world's largest centers of IT-outsourcing business entities (CEE IT Outsourcing Review, 2010).

Such a high position of Ukraine affirms that: 1) the education level of our specialists is high; 2) the level of confidence of foreign companies and international experts to Ukrainian IT-professionals is favourable; 3) companies and specialists working in Ukraine, pay taxes, spend their salary inside the country, and thus facilitate the economic development. However, it is also a symptom that there is a mass outflow of new information technologies and breakthrough ideas from Ukraine. Already in 1995 Russian scientists expressed a great concern of hiring their researchers and professionals on the territory of Russia to work for Western firms and asserted that it is one of the most dangerous forms of "brain drain" (Khromov, 1995).

\section{FOREIGN EXPERIENCE TOWARDS “BRAIN GAIN" AND "BRAIN CIRCULATION"}

At the end of XX century different countries mainly in Asia (India, China, Korea and Taiwan) have experienced the exodus of their habitants. Many qualified people have left their motherland. However these nations have managed to overcome this harmful phenomenon. They have created and implemented successful policies which have led to the brain circulation or even to the brain gain (Zweig, D., Fung C. S., 2008):

- The establishment of research funds with the purpose to fund returnees' scientific activities;

- The creation of postdoctoral centers in order to attract overseas Ph. D's to return for postdoctoral positions on the mainland;

- The implementation of new regulations on "incubators" in hi-tech zones for overseas returnees;

- The establishment of world-class universities;

- The attraction of venture capital;

- The development of digital infrastructure in order to attract IT companies; 
- The remuneration of returnees corresponds to the payment in the U.S. (in purchasing power terms);

- The creation of good domestic conditions for returnees (preferential policies giving for returnees especially better living and working conditions);

- The diverse and active cooperation with scientific Diaspora.

Even European governors were concerned about the mass departure of their high-skilled citizens during 1980-1990's mainly to the United States and Canada. Thus, they conducted effective actions for the returning of their scientists and attracting promising young scientists from the third countries (R. Daugeliené, R. Marcinkevičienè, 2009, P. Giannoccolo, 2009):

- The creation and implementation of programmes stimulating scientists' mobility (Marie Curie, "Blue card" etc.);

- The accreditation of foreign diplomas;

- The simplified visa system for qualified professionals (particularly in UK and Germany);

- The reduction of cultural (linguistic) barriers (e.g. there is allowed to teach in English language, in universities);

- The incentives and facilitations to the researcher's family (the partner's career, children's education or day-care, suitable accommodation and obligations remaining in the home country etc.);

- The incentives and facilitations to the researchers and theirs career (personal assistance with legal and practical problems);

- Various Grants and Scholarships to young researches (UK, Germany. Finland. France etc.)

- The tax reduction and bilateral taxation;

- The marketing and recruiting policies (Some countries implement marketing and recruiting policies directly oriented to attract foreign researchers);

- The support for intellectual property rights (Financial support for start-ups and spin-offs varies widely from one Member State to another).

- The increase in financing of R\&D (up to $3-4 \%$ of GDP).

\section{RECOMMENDED ACTIONS FOR THE ESTABLISHMENT OF THE "BRAIN CIRCULATION" IN UKRAINE}

Foreign experience stresses, that the brain drain phenomenon could be more effectively suppressed via brain gain policy measures, rather than searching for answers and focus on the reasons leading to emigration of highly skilled professionals. There could be highlighted that if a country becomes an attractive place for the international knowledge workers, it will also be attractive enough for the national "brain" to stay in the country (R. Daugèlienè, R. Marcinkevičienè, 2009).

In order to facilitate the phenomenon of "brain circulation" of Ukrainian scientists and taking into account Ukrainian realities of limited state funding possibilities, we highly recommend the following actions:

1. To remove administrative and institutional barriers which hinder the international cooperation in education and science, namely:

- to accelerate the adoption of the new version of Law of Ukraine "About higher education", which ensures universities' autonomy for free coordination of internal and external academic mobility and brings the third cycle of higher education to the world requirements;

- to establish a simplified visa system for researchers and their families with the most visited countries (in particular, an agreement on visa regime is already signed with Poland, but need also to be ratify with other countries as U.S., Canada, Germany, Israel, etc.); 
- to achieve the accreditation of Ukrainian diplomas abroad and to simplify nostrification of foreign degrees in Ukraine;

- to revise the conditions of labour contract with scientists who are on temporary internships abroad in order to save their workplace in Ukraine;

- to establish a simplified customs barriers for transportation scientific equipment and units;

- to create and to maintain the Ukrainian scientists' mobility Internet portal.

2. To development and implement the national program aimed to encourage the returning process of Ukrainian scientists from abroad. In this case it is important to use the experience of Asian and EU countries, like Czech Republic, Estonia, Hungary and others.

3. To create the attractive domestic conditions for returnees on the basis of national research institutes and universities. Particularly:

- to create the virtual research centers using modern interactive means of communication;

- to create the "mirror laboratories", using the existing foreign lab as a model and its activities that are linked to the foreign work as the original (Semyanov, 2007);

- to maintain and develop cooperation with Ukrainian scientists who already live and work abroad migration network. There is a popular interpretation, that Diasporas are one of the most important factor stimulating brain circulation as well as economics development.

- to give the organizational, informational, diplomatic and financial support to migration networks abroad, using their ability to spread the information among migrants about returning, employment or opening their own business in motherland;

4. To stimulate Ukrainian attractiveness for researches and create favourable conditions for the professional growth of young scientists:

- to create and maintain competitive "technological parks" that must be opened to international cooperation;

- to develop and support the innovation infrastructure, technology transfer centers and to ensure their active representation via Internet;

- to support centers for scientific and talented youth within the universities;

- to enlist the business sector in order to increase laboratory's equipment base;

- to establish of world-class universities;

- to regulate the national venture market (in particular the list of entities that are subjected for venture financing);

- to introduce the beneficial taxation system for researchers and idea creators;

- to solve the housing problem of young scientists, their families and honored returnees (using the instruments of preferential credits or official dwelling).

- to improve significantly the conditions of payment for scientific work, the number of existing domestic grants and the rate of scholarships for young scientists etc.

5. To reduce the emergence of the negative side effects from academic mobility, it is extremely important to conduct the nationwide monitoring every 3-4 years concerning as many programs and areas of academic mobility as possible. Collected and analyzed data will allow both the government and universities to change the priorities and to direct the resources to the interesting fields of research.

"Brain circulation" is an excellent antidote to chronic "brain drain". Coherent and efficient migration regimes will help making the most of "brain circulation". 


\section{CONCLUSIONS}

The analysis of the migration mood of Ukrainian youth based on the sociological surveys and empirical data enables to make the conclusion that the level of potential intellectual outflow of Ukrainian youth tends to increase. It includes the high rates of labour migration to the U.S., Russia, Germany and other countries; the ongoing number of students involved into the education and training mobility and also the increasing expansion of outsourcing international companies hiring youth in Ukraine but taking away their intellectual capital abroad. Such a tendency is one of the displays of labour force and capital globalization that sooner or later would appear in Ukraine.

The value of international cooperation shouldn't be diminishing, but the potential risks for the economic and demographic security of the country must be predicted. Considering Ukrainian realities, when it is almost impossible to increase the state financial input into $\mathrm{R} \& \mathrm{D}$ (even to the legitimate level of $1.7 \%$ of GDP) it is of a great importance to prevent the next wave of intellectual migration and to create an attractive conditions for "brain circulation" development. There were suggested recommended actions for the establishment of the "brain circulation" in Ukraine. Ukrainian's government should implement social and economical actions towards the establishment of this phenomenon. This includes the removal of administrative and institutional barriers which hinder the international cooperation in education and science, the development of the national program aimed to encourage the returning process of Ukrainian scientists from abroad, the establishment of good domestic conditions for returnees and periodic nationwide monitoring of the outbound flows of Ukrainian students and scientists.

\section{REFERENCES}

Annual Report of the German Academic Exchange Service (2010) [Online], available: http://www.daad.de/imperia/ $\mathrm{md} /$ content/presse/jahresbericht_2010_en_internet.pdf http://www.radiosvoboda.org/content/article/2091427. html 25

Lowell, B.L., Findlay, A, Stewart, E. (2004), Brain strain. Optimising highly skilled migration from developing countries, London, Institute for Public Policy Research, Asylum and Migration. Working Paper 3. . [Online], available: http:// www.ippr.org/images/media/files/publication/2011/05/brainstrain_1365.pdf

Balakirieva, O., Valkovana, O. (2006), The problems of employment and youth migration mood, Kyiv: Bibliography.

Boyko Z. (2010) The problems of labor migration of Ukrainian youth, Informational department "Discorpus", [Online], available: http://dipcorpus- info.at.ua/news/proekt_problema_trudovoji_emigraciji_ukrajinskoji_molodi/201005-26-70

CEE IT Outsourcing Review: Country Overview (2010) [Online], available http://itonews.eu/country-overview/.

Daugèlienė, R., Marcinkevičienè, R. (2009), Brain Darin problems in Lithuania - possible actions for its solution via brain gain. European Integration Studies. No 3. [Online], available: http://www.ktu.lt/lt/mokslas/zurnalai/eis/03/Daugeliene_Marcinkeviciene_2009_14-22p.pdf.

Europe without barriers (2011), Document security and migrational policy, Kyiv: Fund "Democratic Initiatives" jointly with the "Ukrainian Sociology Service". [Online], available: http://novisa.org.ua/upload/file/SECURITY\%20OF\%20D OCUMENTS\%20UKR.pdf.

Filipova N. (2011), Socio-economic aspects of international labour migration, Collection of scientific works. Kyiv. Issue 26.

Foreign labour migration Ukraine (2009) Kyiv: Ukrainian Centre for Social Reforms. [Online], available: http://openukraine.org/doc/BK-MIGR-END.pdf.

Fulbright Ukraine [Online], available: http://www.fulbright.org.ua. 
Giannoccolo, P. (2009), Brain Drain Competition, Policies in Europe: a Survey, [Online], available: http://www.morebrain.net/index_htm_files/Brain_Drain_competition_policies_in_Europe.pdf.

International Migration in a Globalizing World: The Role of Youth, Population Division Technical Paper No. 2011/1. New York, 2011.

Khromov, H. (1995), The science that we loose, Moscow: Cosmoinform. P. 15.

Kipen, V. (2011) Experts discussed the "simple things" for a successful migration policy [Online], available: http://novisa.com. ua/analitic/eksperti-obgovorili-/ua.

Libanova, E., Poznyak, O. ed. (2002), External labor migration in Ukraine, Kyiv: National Academy of Sciences in Ukraine.

Nikilaevskyy, V., Prohorenko, N. (2010) The current tendencies in intellectual migration in Ukraine, The Methodology, theory and practice of sociological analysis of modern society. Issue 16. Kharkiv: KhNU named after Karazin. [Online], available: http://www.nbuv.gov.ua/portal/Soc_Gum/Mtpsa/2010_16/Nikol_Pr.pdf.

Pirozhkov, S., Malinovska, O., Khomra O. (2003) External labor migration in Ukraine: socio-economic aspect, Kyiv: NIMPB.

Pyatkovska, O. (2012), For the first time on a scientific level Church and State discussedthe issue of migration [Online], available: http://dyvensvit.org/suspilstvo/178-suspilstvo-statti/6409-vpershe-na-naukovomu-rivni-cerkva-i-derzhava-obgovoryly-problemu-migraciji.

Semyanov A. (2007), "The brain return": tactic of mirror labs. Open Economy [Online], available: http://opec.ru/analize_doc.asp?d_no=63767.

StarTravel (2012), Most of the Ukrainian youth - potential migrant workers, Radiosvoboda [Online], available: http://www. radiosvoboda.org/content/article/2091427.html.

Statistic bulletin (2010), No. 2. Kyiv: State Statistics Service of Ukraine. 126 p.

Study on the organisation of doctoral programmes in EU neighbouring countries, Final synthesis, Technopolis Group, December 2010, [Online], available: http://ec.europa.eu/education/more-information/doc/2011/doctoralreport_en.pdf

Supel Y. (2010). Ukraine in FP7 EU. Warsaw-Kyiv. [Online], available: http://www.achem.univ.kiev.ua/news/pdf/Ukra inian\%20participation\%20in\%20FP7_07.pdf.

Tarchenko, N. (2010), More and more Ukrainian students want to study abroad, Interfax-Ukraine [Online], available: http://www.kyivpost.com/content/ukraine/more-and-more-ukrainian-students-want-to-study-abr.html\#. UAMH4ORv-to.

The European Higher Education Area in 2012: Bologna Process Implementation Report Education, Audiovisual and Culture Executive Agency, Brussels, 2012.

The National TEMPUS Office in Ukraine [Online], available: http://eeas.europa.eu/delegations/ukraine/projects/youth/ tempus_uk.htm.

Zweig, D., Fung C.S., Han D. (2008), Redefining the Brain Drain: China's “Diaspora Option”, Science, Technology \& Society, $1-33$. 